\title{
FRESHWATER FISH CONSIDERATIONS FOR AQUATIC CONSERVATION SYSTEMS PLANNING IN NOVA SCOTIA
}

\author{
YOICHIRO KANNO* and KAREN BEAZLEY \\ School for Resource and Environmental Studies, Dalhousie University, \\ Halifax, Nova Scotia B3H $3 / 5$ \\ *Present address: Embassy of Japan, Ottawa, Ontario K1N 9E6
}

\begin{abstract}
Freshwater ecosystems have suffered severe losses of biodiversity as a result of human activities, however there has been limited attention to freshwater conservation planning. Key criteria for biodiversity conservation in the terrestrial realm (i.e., representation, special elements and focal species) may also be useful in freshwater systems. Thus, we explore freshwater fish conservation in Nova Scotia (NS) with respect to these key criteria. Representation of freshwater fish habitats and communities should include examples of typical and unique biogeographical regions, streams, rivers, lakes, ponds, wetlands, and community assemblages. Special elements include critical habitat for species- and communities-at-risk, and hotspots of diversity and rarity. Sufficient habitat to maintain viable populations of focal species should also be conserved. Focal species 1 ) are functionally important, such as those at higher trophic levels and key prey, 2) have large-area requirements or are wide ranging, 3) are indicators of habitat quality and/or management practices, and 4) are flagships, such as charismatic and vulnerable species that garner support for aquatic conservation. Considerations of representation, special elements and focal species serve to identify important areas for conserving freshwater fish species, assemblages and habitat in NS. Intolerant and coldwater communities and species such as Atlantic whitefish Coregonus huntsmani, Atlantic salmon Salmo salar, brook trout Salvelinus fontinalis, lake trout Salvelinus namaycush and rainbow smelt Osmerus mordax warrant conservation attention in NS due to their relatively high ecological importance and/or vulnerability. Other factors for selecting among potential sites for conservation are stability and resilience to broader cross- or transboundary threats such as exotic species, global warming, and acidification. Furthermore, as a consequence of the fluidity and connectivity of aquatic ecosystems, conservation planning should encompass a relatively large portion of selected drainages. Our approach may be useful for other temperate regions in North America.
\end{abstract}

En raison des activités humaines, les écosystèmes d'eau douce ont subi de graves pertes sur le plan de la biodiversité; cependant, on a prêté qu'une attention limitée à la planification de la conservation des eaux douces. Les critères principaux en matière de conservation de la biodiversité dans le domaine terrestre (à savoir la représentation, les éléments spéciaux et les espèces focales) peuvent aussi être utiles pour les eaux douces. Ainsi, nous examinons la conservation des poissons d'eau douce en Nouvelle-Écosse en fonction de ces critères. La représentation des habitats et des communautés de poissons d'eau douce doit comprendre des exemples de régions biogéographiques, de cours d'eau, de lacs, d'étangs, de milieux humides et d'assemblages de communautés typiques et uniques. Parmi les éléments spéciaux, on compte l'habitat essentiel pour les espèces et les communautés en péril ainsi que les hauts lieux de diversité et de rareté. De plus, il faut conserver suffisamment d'habitat pour maintenir des populations viables des espèces focales. Ces espèces sont importantes sur le plan fonctionnel (qu'on pense aux espèces des niveaux trophiques supérieurs et aux proies principales), ont besoin de beaucoup d'espace ou parcourent un vaste territoire, sont des indicateurs de la qualité de l'habitat ou des résultats des efforts de gestion et jouent un rôle symbolique, comme les espèces charismatiques et vulnérables qui suscitent l'appui en faveur de la conservation des milieux aquatiques. Les facteurs comme la représentation, les éléments particuliers et les espèces focales permettent de repérer les zones importantes pour la conservation des eaux douces, des espèces de poisson, des assemblages et des habitats. En raison de leur importance écologique relativement élevée ou de leur vulnérabilité, il faut accorder de l'attention sur le plan de la conservation aux communautés et aux espèces intolérantes et d'eaux froides, comme le corégone de l'Atlantique (Coregonus huntsmani), le saumon atlantique (Salmo salar), l'omble de fontaine (Salvelinus fontinalis), le touladi (Salvelinus namaycush) et l'éperlan (Osmerus mordax). D'autres facteurs servent au choix de sites potentiels de conservation, comme la stabilité et la résilience à des menaces transfrontalières, qu'on pense aux espèces exotiques, au réchauffement planétaire et à l'acidification. De plus, la planification devrait couvrir une part relativement grande des bassins hydrographiques choisis. Notre approche peut s'appliquer à d'autres régions tempérées de l'Amérique du Nord.

* Author to whom correspondence should be addressed. 


\section{Introduction}

Temperate freshwater fish have suffered severe losses of biodiversity at genetic, population, species, assemblage, and landscape levels due to human activities (Hughes \& Noss 1992, Moyle \& Leidy 1992). In North America, by 1989, 27 species and 13 subspecies of freshwater fish were extinct (Miller et al. 1989), and 364 species were considered to warrant protection because of their imperilment and rarity (Williams et al. 1989). Although not widely recognized by the public, the proportions of freshwater organisms facing extinction are higher than those of terrestrial species (Karr \& Chu 1999, Ricciardi \& Rasmussen 1999). Habitat conversion, degradation and fragmentation are the primary causes of fish decline in North America, followed by introduction and invasion of aggressive exotic species, and chemical pollution; additional threats include over-exploitation, acidification and global warming (Miller et al. 1989, Moyle \& Leidy 1992). In spite of this apparent loss and degradation, there has been limited attention to aquatic conservation systems planning both in theory and in practice (Maitland 1985, Moyle \& Sato 1991).

Biodiversity considerations for conservation systems planning include a combination of three main sets of criteria: representation, special elements and focal species. (Noss et al. 1999). Conservation planning based on a synthesis of these three sets of criteria has only recently been applied to terrestrial systems. We believe, however, that they may also provide a framework for aquatic conservation planning. This paper explores freshwater fish considerations with respect to each of these criteria in Nova Scotia (NS), and discusses considerations required to determine the spatial extent and distribution of a system of aquatic conservation areas.

\section{Representation}

Representation is a coarse-filtered approach in which examples of each typical and unique region or ecosystem are selected for conservation. The aim is to protect biodiversity at the ecosystem, community or landscape level, while at the same time capturing many species and genetic variability. In selecting potential sites for conservation within each ecosystem type, preference is usually given to those with the greatest ecological integrity, or with the most natural characteristics or pristine qualities. Representation alone, however, is an insufficient basis for conservation system planning, since some species are not likely to be captured by the representative sample, such as rare species, and other species will require larger habitat area and/ or volume and other mitigation measures to maintain population viability over time. Thus, the value of a coarse-filter or representation approach to conservation is not as a stand-alone component, but rather as complementary to fine-filter considerations, such as special elements and focal species.

In freshwater systems, representation could likewise entail the selection of examples of typical and unique aquatic systems, as defined by biogeographic diversity, system types (e.g., lake, stream, pond), and fish assemblages (e.g., cold-, cool-, warm-water assemblages). To achieve representation, the types and distribution of fish communities in NS would need to be defined, and at least one example of each type would need to be conserved or protected. Ideally, more than one example should be protected so as to incorporate redundancy into the system as insurance against the loss of whole communities in the event of natural or anthropogenic disturbances within the protected area. In cases where protection is afforded to more than one population in a connected system, redundancy can also facilitate the recolonization of disturbed 
reaches from adjacent populations. Our approach focuses on representation at the fish-community level, since information at this level is relatively available. The small number and low endemism of freshwater fish in NS (Gilhen 1974) implies the existence of a relatively small number of fish community types.

Distributions of native freshwater fishes are primarily influenced by abiotic conditions within which biological interactions delimit the ecological niche (Shuter \& Post 1990, Rahel \& Hubert 1991). As such, fish communities show distinct distributional patterns in conjunction with variation in abiotic environments. A series of studies has found a good correspondence between ecoregions and fish distributions (Rohm et al. 1987, Whittier et al. 1988). Hughes et al. (1990) suggest that aquatic ecoregions can be defined by terrestrial features such as land use, soil, natural vegetation, and land form, based on an assumption that the nature of aquatic environments is determined by their surrounding landscapes. However, other studies indicate that local environmental variables such as water temperature, stream size, stream gradient, and water quality are more important than broader ecoregional characteristics in explaining patterns of fish distributions (Newall \& Magnuson 1999, Waite \& Carpenter 2000). Longitudinal changes in abiotic factors such as water temperature and stream size are typically accompanied by fish community changes. For example, in many temperate regions of North America, headwater streams dominated by coldwater trout-sculpin assemblages are often replaced by warmwater minnow-sucker assemblages in downstream reaches (Rahel \& Hubert 1991). Such linear patterns, however, do not occur strictly as a consequence of local influence on habitat conditions (e.g., coldwater seepage in downstream alluvial plains creates thermal conditions favourable for coldwater species) (Fausch et al. 2002).

In accordance with studies in other regions, the most consistent pattern in fish distributions observed in NS is a distinction between fish assemblages found in coldwater, coolwater and warmwater habitats (Magnuson et al. 1979). Fish assemblages from each thermal guild seem to exhibit habitat segregation at a broad scale. For example, in River Philip watershed, Cumberland County, brook trout is typically associated with cold headwater streams, whereas cool-/warm-water and/or relatively tolerant species such as blacknose dace and white sucker dominate fish assemblages at warmer and/ or impacted reaches (Kanno 2002). Peterson \& Martin-Robichaud (1989) identified five lake-fish assemblages in NS based primarily on acidity and lake-surface area, but suspected that water temperature was another important factor. Peterson \& Gale (1991) also observed that the composition of fish communities in a southern NS catchment changed with acidity and water temperature.

Another important local factor in NS, as elsewhere, may be the type of aquatic habitat, such as stream, lake, or pond. Several species in NS prefer a certain habitat type; for example, northern redbelly dace and pearl dace are associated with relatively slow-flowing waters (Gilhen 1974). In addition, even when a species is commonly found in both lotic (flowing-water such as streams and rivers) and lentic (standing-water such as lakes and ponds) habitats, each group typically exhibits a different life-history strategy and thus may individually warrant conservation efforts (Epifano et al. 2003, Meka et al. 2003). For example, some brook trout populations spend their entire life in streams or in lakes. In addition, other populations use both habitats to complete their life history.

When discussing fish community patterns in NS, the zoogeography of its freshwater fish also warrants attention. Due to the colonization history of freshwater fish after the last glaciation, the highest number of freshwater fish species in NS is found in areas closer to the continental mainland, such as in Cumberland County, and the number of species diminishes towards both ends of the peninsular province, which are further 
away from the continental colonization source (Gilhen 1974). Thus, this zoogeographic character determines the regional species pool available for fish community composition.

In selecting representative communities, it is also important to differentiate natural fish assemblages from artificial ones, and provide protection for the former. Examples of artificial assemblages are those dominated by exotic species and with species that can tolerate degraded habitats. The introduction of aggressive exotic species can result in artificially increased species richness in the short term, but often results in extirpation of native fish species and decreased diversity over time. Environmental degradation in warmwater streams typically results in reduced species richness (Karr et al. 1986), whereas degraded coldwater streams have higher numbers of species than they naturally would (Lyons et al. 1996, Mundahl \& Simon 1998, Kanno 2002). In coldwater streams, which are common in NS, artificial increases in species richness should not be used to argue for habitat protection (Lyons et al. 1996). Future research should determine the types and numbers of fish assemblages that ideally and realistically represent the native freshwater fishes in NS.

Other levels of biological diversity, such as genetic, morphological, population, and landscape diversity, should also be considered, if available (Hughes \& Noss 1992). At the genetic level, for instance, the Inner Bay of Fundy populations of Atlantic salmon are considered unique and are designated as an endangered population by the Committee on the Status of Endangered Wildlife in Canada (COSEWIC). However, information at levels other than species is not readily available for most freshwater fish in NS. An interim solution to this serious lack of specific data may be to capture diverse geographic representation in the selection of drainages for conservation, based on the assumption that the genetic differences between populations in two distant drainages are larger than those in two adjacent or neighboring drainages (Spidle et al. 2003). Thus, if an opportunity exists to select among several drainages of similar ecological values, geographical separation or distance between drainages may serve as a surrogate for genetic diversity. Another consideration in selecting representative drainages is the current extent and quality of natural land cover in riparian zones and surrounding portions of watersheds. Watersheds with the least anthropogenic disturbances are likely to retain higher levels of ecological integrity and thus may be of higher conservation value, considering, for example, the important functions of riparian zones (Kauffman et al. 1997). Alternatively, remnant examples of drainages that have been widely converted and degraded may also warrant conservation attention as a result of their irreplaceability and the existence of imminent threats.

Finally, the consideration of taxa other than fish, such as frogs or benthic macroinvertebrates, may also be useful in classifying representative aquatic ecosystems, especially in regions with depauperate fish fauna such as NS (Kerans \& Karr 1994, Moyle \& Marchetti 1998, Karr \& Chu 1999). For example, Moyle \& Marchetti (1998) combined information on native ranid frogs and fish to develop a watershed-index of biotic integrity in California, which could be used for identifying priority drainages for conservation.

\section{Special Elements}

Special elements include critical habitat for species- and communities-at-risk, and hotspots (geographic clusters) of diversity and rarity. Species-at-risk are designated on the basis of small and declining population size and distribution trends, number of occurrences, and threats to population and/or habitat (Elderkin \& Boates 1996). 
Freshwater fish species that are designated by COSEWIC as at-risk nationally are Atlantic whitefish and the Inner Bay of Fundy population of Atlantic salmon. Provincially, nine species are considered at-risk: four are red-listed and five are yellow-listed, with red-listed species being more threatened (NSDNR 2002) (Table 1). However, the only freshwater fish currently designated as at-risk under Nova Scotia's Endangered Species Act is the Atlantic whitefish. The Millipsigate Lake/Petite Rivière System in Lunenburg County may be the last remaining occurrence of this species globally (Gilhen 2002).

Table 1 NS red-listed and yellow-listed freshwater fish

\begin{tabular}{ll}
\hline Red-listed & Yellow-listed \\
\hline Atlantic whitefish & brook trout \\
Atlantic salmon & lake trout \\
Atlantic sturgeon & alewife \\
Striped bass & fourspine stickleback \\
& pearl dace \\
\hline
\end{tabular}

(Source: NSDNR 2002)

Salmonids and other species generally found in coldwater and intolerant assemblages seem disproportionately threatened in NS and may thus represent communities- or assemblages-at-risk; five of the nine red- and yellow-listed species are associated with the coldwater guild (Table 2). The proportion of listed species that are associated with coldwater assemblages is high (56\%) in comparison with the proportion of native species in NS that are associated with coldwater assemblages (25\%) (Kanno 2002). In comparison to species found in cool- and warm-water assemblages, coldwater species are typically more susceptible to temperature increases, which often result from human activities such as removal of riparian vegetation, water removal, and anthropogenically-induced climate change. In addition, fishes from the coldwater guild in NS also tend to be intolerant species (Table 2), which are sensitive to environmental degradation such as physical habitat alteration and chemical pollution, and are usually the first to disappear when habitat degradation proceeds (Karr et al. 1986, Lyons et al. 1996). Some intolerant coldwater species are also considered vulnerable because of additional factors such as limited distributional range (Atlantic whitefish and lake trout), and late reproductive maturity (Atlantic salmon and lake trout) (Table 3).

While broad-scale habitat segregation occurs among coldwater, coolwater, and warmwater assemblages it is important to note that the actual distributions of each guild may not necessarily reflect preferred macro-habitats. Species that are sensitive to ecological processes such as competition and predation may remain in or retreat to sub-optimal habitats as a survival tactic, especially when inter-specific competition and predation risk are high within optimal habitats. Caution should be exercised to avoid conserving sub-optimal habitats alone as a long-term strategy for conservation of these species.

Hotspots of diversity and rarity comprise another component of special elements. Many fish species are geographically restricted and numerically rare where they occur (Sheldon 1988). In addition, fish species that are endemic, restricted to a small area, or occupy a single drainage basin, (i.e., rare species) are more likely to become at risk, as shown in California by Moyle \& Williams (1990). Hotspots of diversity and rarity represent areas where many rare species occur, thus they may present an opportunity to conserve several of these species within a smaller number of sites. 
Table 2 Tolerance and thermal guilds of the 33 freshwater fish recorded in NS

\begin{tabular}{|c|c|c|c|c|}
\hline \multicolumn{5}{|c|}{ Higher vulnerability } \\
\hline \multirow{2}{*}{$\begin{array}{l}-\Delta \\
-\end{array}$} & & Coldwater species & Coolwater species & Warmwater species \\
\hline & $\begin{array}{l}\text { Intolerant } \\
\text { species }\end{array}$ & $\begin{array}{l}\text { Atlantic whitefish ** } \\
\text { Coregonus huntsmani } \\
\text { Atlantic salmon** } \\
\text { Salmo salar } \\
\text { brook trout* } \\
\text { Salvelinus fontinalis } \\
\text { lake trout* } \\
\text { Salvelinus namaycush } \\
\text { rainbow smelt } \\
\text { Osmerus mordax }\end{array}$ & $\begin{array}{l}\text { blacknose shiner } \\
\text { Notropis heterolepis } \\
\text { brook stickleback } \\
\text { Culaea inconstans } \\
\text { Atlantic tomcod } \\
\text { Microgadus tomcod }\end{array}$ & $\begin{array}{l}\text { Atlantic sturgeon** } \\
\text { Acipenser oxyrinchus } \\
\text { striped bass** } \\
\text { Morone saxatilis }\end{array}$ \\
\hline & $\begin{array}{l}\text { Intermediate } \\
\text { species }\end{array}$ & $\begin{array}{l}\text { northern redbelly dace } \\
\text { Phoxinus eos } \\
\text { lake chub } \\
\text { Couesius plumbeus } \\
\text { pearl dace* } \\
\text { Magariscus margarita }\end{array}$ & $\begin{array}{l}\text { sea lamprey } \\
\text { Petromyzon marinus } \\
\text { alewife* } \\
\text { Alosa pseudoharengus } \\
\text { common shiner } \\
\text { Luxilus cornutus } \\
\text { fall fish } \\
\text { Semotilus corporalis } \\
\text { threespine stickleback } \\
\text { Gasterosteus aculeatus } \\
\text { fourspine stickleback* } \\
\text { Apeltes quadracus } \\
\text { ninespine stickleback } \\
\text { Pungitius pungitius } \\
\text { white perch } \\
\text { Morone americana } \\
\text { yellow perch } \\
\text { Perca flavescens }\end{array}$ & $\begin{array}{l}\text { blueback herring } \\
\text { Alosa aestivalis } \\
\text { American shad } \\
\text { Alosa sapidissima } \\
\text { Atlantic silverside } \\
\text { Menidia menidia } \\
\end{array}$ \\
\hline- & $\begin{array}{l}\text { Tolerant } \\
\text { species }\end{array}$ & & $\begin{array}{l}\text { blacknose dace } \\
\text { Rhinichthys atratulus } \\
\text { creek chub } \\
\text { Semotilus } \\
\text { atromaculatus } \\
\text { white sucker } \\
\text { Catostomus } \\
\text { commersoni } \\
\text { mummichog } \\
\text { Fundulus heteroclitus }\end{array}$ & $\begin{array}{l}\text { American eel } \\
\text { Anguilla rostrata } \\
\text { golden shiner } \\
\text { Carassius auratus } \\
\text { brown bullhead } \\
\text { Ameiurus nebulosus } \\
\text { banded killifish } \\
\text { Fundulus diaphanus }\end{array}$ \\
\hline
\end{tabular}

Source: Kanno 2002

Note: Species with two asterisks $\left({ }^{* *}\right)$ are red-listed by the province, while species with one asterisk $\left({ }^{*}\right)$ are yellow-listed (NSDNR 2002 
Table 3 Comparison of freshwater fish in NS with intolerance and other vulnerability characteristics

\begin{tabular}{lll}
\hline Intolerant species & $\begin{array}{l}\text { Species with limited } \\
\text { distributional range in NS }\end{array}$ & Late maturity species \\
\hline Atlantic whitefish** & Atlantic whitefish** & $\begin{array}{l}\text { Atlantic salmon** } \\
\text { lake trout** }\end{array}$ \\
$\begin{array}{l}\text { Atlantic salmon** } \\
\text { brook trout** }\end{array}$ & $\begin{array}{l}\text { lake trout** } \\
\text { pearl dace } \\
\text { lake trout** }\end{array}$ & $\begin{array}{l}\text { American eel } \\
\text { blacknose dace }\end{array}$ \\
$\begin{array}{l}\text { Atlantic sturgeon } \\
\text { striped bass }\end{array}$ & fall fish & \\
rainbow smelt & & \\
northern redbelly dace & & \\
blacknose shiner & & \\
Atlantic tomcod & & \\
brook stickleback & & \\
\hline
\end{tabular}

(Source: Compiled from Beazley 1998, Halliwell et al. 1998).

Note: species with two asterisks $\left({ }^{* *}\right)$ are coldwater species, while those with one asterisk $(*)$ are coolwater species.

\section{Focal Species}

The focal species concept suggests that a carefully chosen suite or subset of species can serve as surrogates for others, and thus form a multi-species umbrella for conservation planning. A suite of focal species should include those that function in one or more of four different ways, as keystone, umbrella, indicator and/or flagship (Miller et al. 1999). Keystone or functionally important species play a critical role in the community, such as top predators, large herbivores, key prey, and those that transform the system, as do beavers. Umbrella species have large-area and/or volume requirements, or migrate or range widely; as a consequence, protection of sufficient habitat for these species may also serve to protect species with overlapping but smaller habitat requirements. Habitat quality indicator species are those most affected by changes in the quality of the habitat and/or management practices, thus warranting conservation attention. If they are also to be used as indicators for conservation monitoring purposes, they should also meet other pragmatic criteria, such as distribution over a broad geographic area, sampling ease and cost-effectiveness, and differential responses to natural trends and anthropogenic disturbances. Flagship species garner support for conservation initiatives because they are charismatic and/or vulnerable.

Freshwater fish are arguably good candidates for focal species (Moyle \& Leidy 1992, Beazley 1998). Fish species often have major effects on the distribution and abundance of other organisms in the waters they inhabit, thus they may serve as keystone or functionally important species. Blueback herring, American shad, alewife, Atlantic salmon, and some species of dace, shiner and stickleback are examples of functionally-important species as predators, prey, or important resources, as identified by experts in NS (Table 4) (Beazley 1998). Species in the Family Cyprinidae (minnows) may constitute important prey species. Losses of these functionally-important species can trigger trophic cascades or other disruptions that affect the entire ecosystem (Terborgh et al. 1999). As a result, it is important to conserve their habitat and other life-history requirements. Functional importance is admittedly a relative factor rather than an absolute, and is also, by definition, associated with the function of certain species or groups of species as opposed to the specific species per se. Thus, there are inherent 


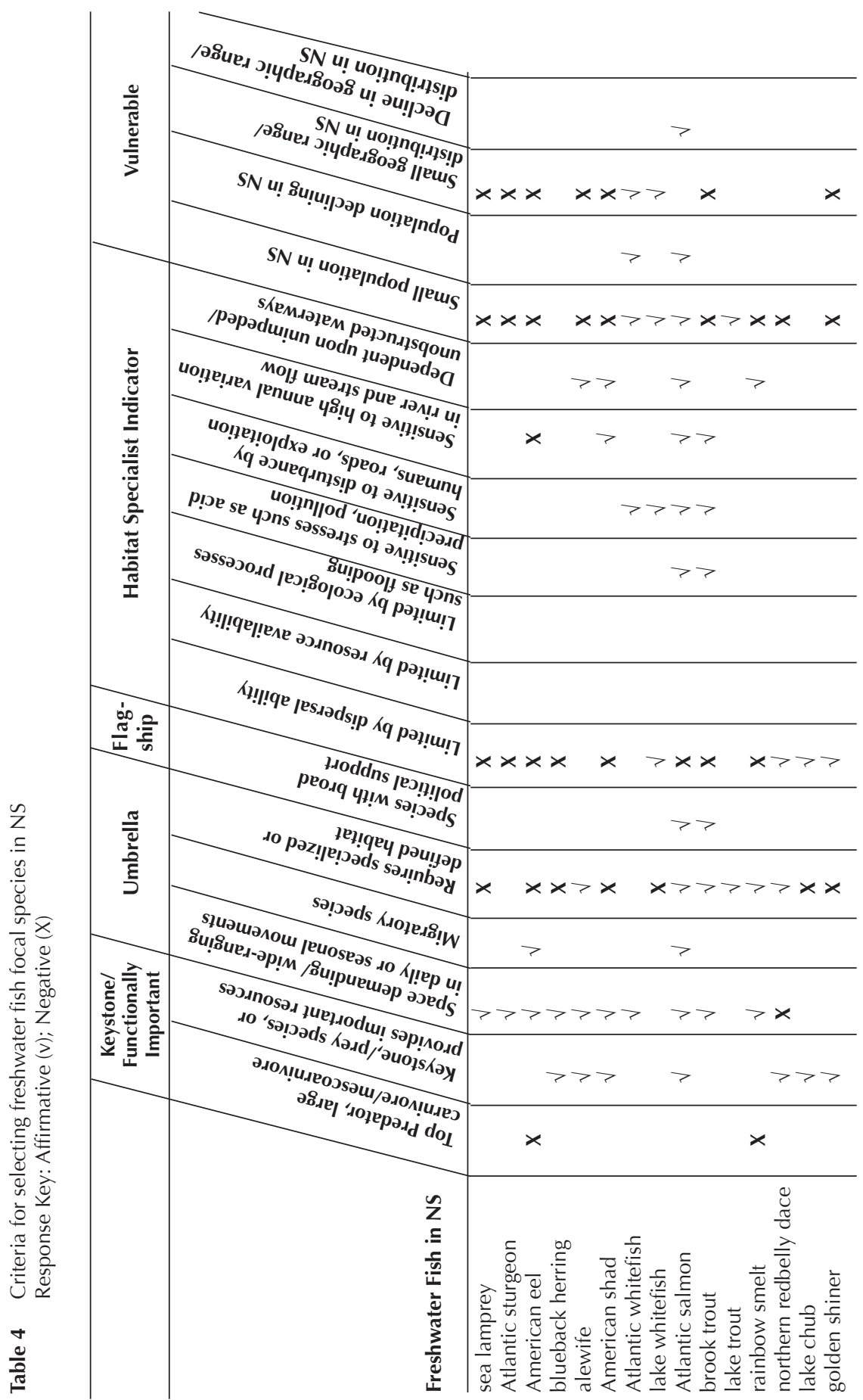




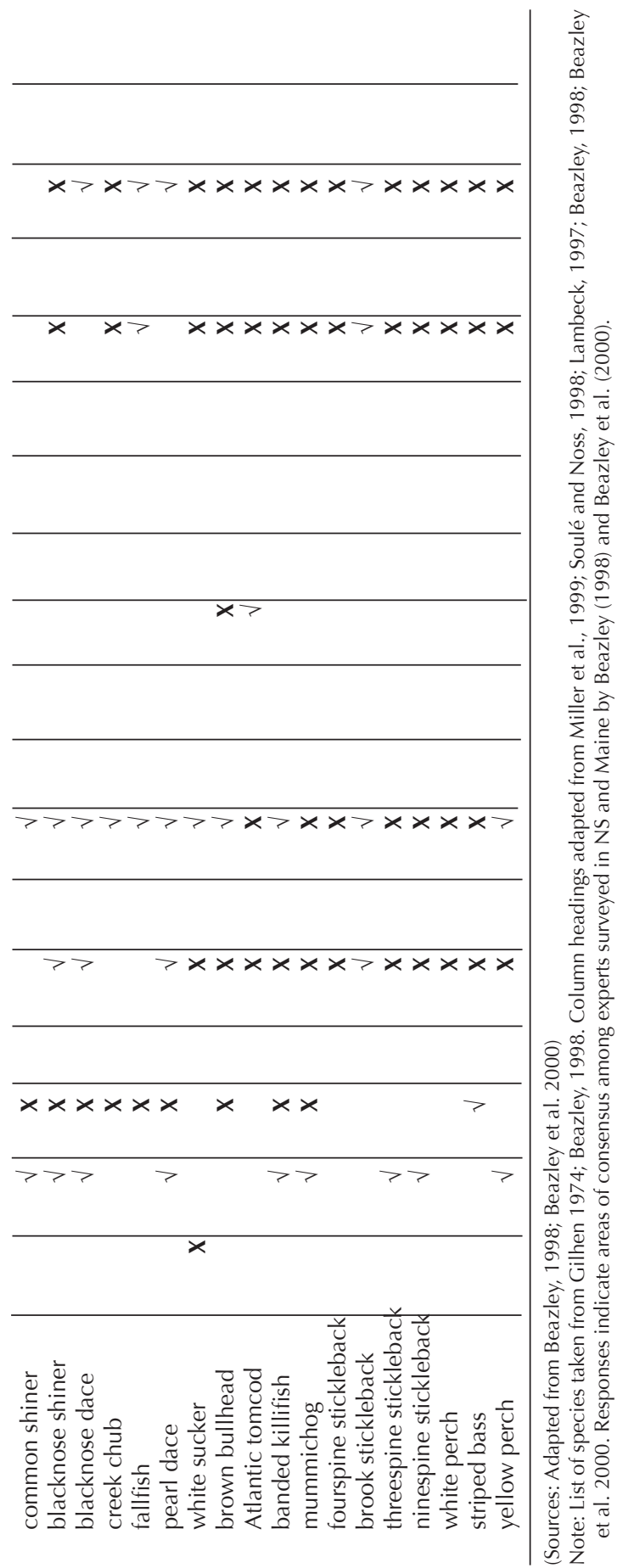


difficulties with identifying specific functionally-important species. Nonetheless, it is important to maintain the critical ecological functions of, for example, predator-prey relationships and it is difficult to do so without attention to particular species performing these roles in any given system.

Diadromous (i.e., anadromous and catadromous) fish range widely in space and can function as umbrellas. Atlantic sturgeon, American eel, Atlantic salmon, sea-run brook trout, alewife, American shad, and striped bass are potential umbrella species in NS (Table 4). Anadromous fish spend part of their life cycle in saltwater and migrate to freshwater to spawn, such as Atlantic sturgeon; catadromous fish spend part of their life cycle in freshwater and migrate to saltwater to spawn, such as American eel. Because various life stages of fish have different habitat requirements and these habitats are often widely separated, spatial heterogeneity and movement among spatially separated habitats are critical (Fausch et al. 2002). Due to complex and changing habitat requirements, the conservation of freshwater fish poses special challenges. However, protection of salmon habitat, for example, could be effective as an umbrella function, since it would contain various types of habitats longitudinally, and thus encompass many other aquatic species and ecosystems.

Freshwater fish are proven indicators of aquatic health, as seen in the development of Indices of Biotic Integrity (IBIs) (Karr et al. 1986, Lyons et al. 1996). These studies suggest that various attributes of fish communities such as species richness and composition, abundance of individual indicators, and trophic function, are useful in assessing the quality of aquatic environments. At the species level, presence and abundance of certain taxa are indicative of particular environmental qualities. Atlantic salmon, for example, may be a watershed-scale habitat quality indicator since they are a pollution susceptible/accumulator species and require unobstructed watercourses (Beazley 1998). Similarly, brook trout are dependant upon high-quality coldwater streams that are often associated with stable groundwater discharge (Picard et al. 2003). Atlantic salmon, brook trout, and striped bass are also management indicator species, since all are vulnerable to exploitation and are legally harvested in NS.

Finally, several species are charismatic, important for sport or commercial fishing, and vulnerable, and thus may garner public support for freshwater conservation. In NS, Atlantic salmon and brook trout are popular sport fishes, though opportunities for fishing these species are declining. Declining wild populations of these species (see, for example, DFO 2000) and consequent loss of opportunities for sport fishing may be effectively used to stimulate public support for their conservation.

Salmonids in NS have characteristics that make them vulnerable to habitat degradation and that serve various focal-species functions in conservation system planning. For example, Atlantic salmon is a species-at-risk and a coldwater, intolerant species sensitive to environmental degradation, is considered to be of functional importance, requires large, unobstructed watercourses and a range of habitats for various life-history stages, and provides sport-fishing opportunities, albeit relatively limited at present, in NS (Beazley 1998). Thus, it is an important focal species, with charismatic, keystone, umbrella, habitat quality and management indicator functions. As a result, it is also a potential flagship species, which could garner public support for aquatic conservation planning.

A multi-species approach is critical, however, in freshwater conservation, as in terrestrial systems; no single species or group of species can serve as surrogate for all species and ecosystems. For example, a conservation system plan based solely on the needs of the most area/volume-demanding fish species will fail to encompass species restricted to other locations and habitat types. Broad-scale segregation occurs among 
coldwater, coolwater, and warmwater habitats as previously noted, and considerations of focal species in all three habitat types are required. It is also important to note that conservation of freshwater systems will require the selection of focal species that depend upon both terrestrial and aquatic habitat, and that include aquatic taxa other than fish (e.g., amphibians). Nonetheless, by accommodating the habitat requirements of a carefully selected suite of freshwater fish, many other aquatic species and ecosystems will also be conserved.

\section{Addressing Broader Threats to Freshwater Fish in Conservation System Planning}

Conservation systems that encompass sufficient aquatic and riparian habitat to maintain freshwater fish will go a long way towards protecting other species, assemblages and ecosystems. The conservation of core areas, functional connections between them and buffer areas should serve to address local threats from habitat destruction, chemical pollution, and exploitation. The ability of conservation systems to address broader transboundary threats such as aggressive exotic species, global warming, and acidification, however, is more limited. For example, in cases where populations of exotic species are established, the creation of a conservation area alone will not serve to address the threat. Transboundary stressors such as global warming and acidification may similarly override efforts to protect habitat through conservation area establishment alone. Nonetheless, careful consideration of these threats in aquatic conservation planning can serve to alleviate or mitigate some of the impacts, such as by selecting areas that are more buffered, stable and resilient than others in response to these stressors.

After habitat conversion, degradation and fragmentation, exotic species introduction and invasion are the most important threat to native fish persistence in North America (Moyle \& Leidy 1992). Aggressive exotics have become a serious management issue in NS; currently, four introduced species (rainbow trout, brown trout, smallmouth bass, and chain pickerel) are widely and successfully reproducing their populations (Gilhen 2002). The piscivorous nature of chain pickerel and smallmouth bass can modify native fish assemblages (Gilhen 1974), and rainbow trout and brown trout are suspected competitors with native salmonids (Fausch 1988). For instance, predation by chain pickerel may be giving a final blow to the already imperiled Atlantic whitefish in Millipsigate Lake/Petite Rivière system (Gilhen 2002). Furthermore, common hatchery practices, such as stocking of harvest-size brook trout, may be having a potentially negative effect throughout NS, since the mass release of hatchery-propagated species is suspected to reduce genetic fitness of wild populations through interbreeding (Epifanio et al. 2003). Since the removal of exotic species is costly and technically difficult (Kauffman et al. 1997), conservation areas should ideally be established in waters that have not been colonized by exotic species, either by introduction or invasion, and that retain a high level of biotic integrity. We stress, however, that exotic species introductions are essentially an awareness or education issue because humans are the principal source of exotic fish introduction to freshwater systems. This is particularly the case for exotic species that have no salinity tolerance and thus cannot invade on their own through oceanic pathways, such as smallmouth bass. Consequently, aquatic conservation planning should be coupled with appropriate management and public/ angler awareness programs, that are ideally supplemented with legislation and regulations that prohibit introductions of exotic species.

Global warming presents significant challenges to the success of aquatic conserva- 
tion systems. Where species of different thermal preferences or associations coexist, coldwater species are more vulnerable to global warming than cool- and warm-water species due to their requirements for colder waters (Rahel et al. 1996, Eaton \& Scheller 1996). If NS warms by $3-4^{\circ} \mathrm{C}$ during this century as predicted (Hengeveld 2000), coldwater habitats could be reduced significantly throughout NS and, as a consequence, conservation of some current coldwater habitats might not be effective. A more effective strategy could be to identify and protect the coldest streams and lakes in NS, which could hypothetically retain the coldwater thermal range after predicted water temperature increases are accounted for. Aquatic ecosystems with regimes that provide cold water could also be identified and protected, such as riparian vegetation (Blann et al. 2002), areas of groundwater seepage (Biro 1998), rivers with thermally-stratified pools (Nielsen \& Lisle 1994), and lake habitats below the thermocline (Olsen et al. 1988). In addition, reaches that cross latitudinal, altitudinal and other temperature and precipitation gradients could be conserved to allow greater opportunity for fish and other species to disperse or migrate to refugia in cooler and/or deeper waters. More northerly and/or higher altitude sites could provide greater protection for species near the upper limits of their temperature tolerances and/or southern limits of their range.

Acidification is another potential impediment to effective conservation of freshwater fish in NS. The southern portion of NS has suffered severely from acidification, since the region is underlain by bedrocks with low buffering capacities (i.e., granite). The region also lies within an area of high deposition rates from industrial emissions upwind in the Great Lakes and eastern seaboard regions (Peterson \& Gale 1991, Davis \& Browne 1996). Southern NS has experienced significant declines in Atlantic salmon populations (DFO 2000), and several minnows such as creek chub have been affected due to their vulnerability to acidification (Smith et al. 1996). Atlantic salmon have an acidity threshold of $\mathrm{pH} 5.4$ below which it cannot maintain viable populations, whereas many rivers in southern NS have pH of less than 5 (Davis \& Browne 1996). Drainages located in areas with relatively higher $\mathrm{pH}$-buffering capacities may represent important refugia for $\mathrm{pH}$-sensitive species and may thus be priorities for conservation to offset the impact of acidification. It is also technically possible to neutralize acidic waters with alkaline substances (e.g., limestone), although it is usually costly (Watt 1986). Reducing stressors at source, however, is a critical goal for addressing acidification problems over the longer term.

While conservation systems may be limited in their ability to address broader, transboundary threats such as aggressive exotics, global warming and acidification, careful planning can serve to minimize the impacts on native freshwater fish diversity. The range limits and tolerances of focal species and assemblages, such as coldwater and intolerant species in NS, provide useful guidelines for conservation systems planning in the context of these threats.

\section{Aquatic Conservation Systems Planning}

The maintenance of aquatic species and ecosystems requires the conservation of carefully selected and relatively large areas. We proposed four criteria for conservation system planning, based primarily on considerations of freshwater fish: (1) representation of native fish communities, and genetic, morphological, population and watershed diversity; (2) presence of special elements such as species- and communities-at-risk, and hotspots of diversity and rarity; (3) habitat requirements for viable populations of focal species; and, (4) ability of the area to mitigate or buffer against threats such as exotic species, global warming, and acidification. While the representation approach 
dictates that a diverse array of native fish community types should be protected (e.g., coldwater assemblages versus warmwater assemblages, lake assemblages versus river assemblages), coldwater and intolerant guilds are especially important in NS due to their vulnerability, thus represent a special element of high conservation value. Coldwater and intolerant species such as salmonids also share several characteristics that suggest they warrant special consideration as focal species, such as functional importance, large-area/volume requirements, habitat- and management-related sensitivities, and charismatic features. For example, Atlantic salmon serves functional, umbrella, habitat quality and management indicator roles, and is a potentially important flagship species.

It is difficult to delineate the spatial extent and distribution of an aquatic conservation system plan to protect freshwater fish in NS. As a general guideline, on the grounds of inter-connectivity of aquatic systems and other considerations, we advocate that relatively large portions of selected drainages be managed for conservation objectives. Aquatic systems are interconnected in several dimensions, particularly in running waters, which are connected longitudinally. Obstructions such as dams affect downstream habitats by modifying flow regime, water quality, and water temperature (Karr \& Chu 1999), as well as upstream reaches by blocking movement of aquatic organisms (Winston et al. 1991). In addition to migratory species, recent evidence suggests that resident fishes often display extensive movement (Peterson \& Bayley 1993, Fausch et al. 2002). Thus, aquatic protection requires relatively large, longitudinally connected areas.

Freshwater systems are also connected horizontally with adjacent lands, and this may be especially true in headwater streams due to their strong linkage to riparian processes (Gomi et al. 2002). The quality and width of riparian zones are often associated with the health of aquatic communities (Barton et al. 1985, Snyder et al. 1998). At a larger scale, the proportions of forested land and other natural ecosystems within drainages are often a predictor of healthy fish communities (Steedman 1988, Frenzel \& Swanson 1996). Therefore, protection of aquatic habitats also necessitates protection of terrestrial areas well beyond typically narrowly-defined riparian buffer zones.

Movements of purely freshwater fish are generally restricted to the watershed in which they occur, since in most circumstances they are not able to traverse oceans and terrestrial ridges. This implies that connectivity in aquatic protected areas is typically discussed in the context of "within a watershed", but not "between watersheds". This suggests that watersheds are an appropriate management unit of aquatic systems.

Finally, there is a general paucity of data and knowledge required for freshwater protected areas planning. Sufficiently-detailed information, such as to define appropriate widths for riparian zones, or to identify seasonal migration patterns and other habitat requirements of species of interest, often does not exist and/or is hard to obtain. As a result of the complexity and uncertainty involved, we argue for extensive conservation of selected drainages or watersheds, as a precautionary and less data-intensive approach than more selective protection of smaller sites in every watershed, though ideally both approaches are required. NS is comprised of 44 geographically small primary watersheds, which can be further divided into several drainage systems (Davis \& Browne 1996). The typically small size of drainage areas in NS provides a pragmatic advantage for aquatic conservation, since smaller areas are required to conserve a good portion of an entire drainage system. Thus, the critical aspect is to select the most appropriate drainage systems in NS for extensive protection, based on systematic and ecologically-sound criteria. 
In conclusion, there is a critical need to systematically plan and establish freshwater conservation systems in NS. Key criteria for terrestrial protected areas planning such as representation, special elements, and focal species, are applicable to conservation of freshwater fish. While an array of native fish communities should be considered, intolerant coldwater fish such as Atlantic salmon and brook trout are disproportionately important and warrant priority attention, due to vulnerability, ecological importance, and umbrella and other surrogate conservation planning functions. The selection of freshwater conservation areas should also take into account the relative abilities of different drainages to buffer or minimize the effects of exotic species, global warming, and acidification. Our approach may be useful for other temperate regions in North America.

\section{Acknowledgements}

We thank an anonymous reviewer for providing thoughtful comments on an earlier draft of the manuscript.

\section{References}

Barton DR, Taylor WD, Biette RM (1985) Dimensions of riparian buffer strips required to maintain trout habitat in southern Ontario streams. N Am J Fish Manag 5:364-378

Beazley K (1998) A focal-species approach to biodiversity management in Nova Scotia. PhD thesis, Dalhousie University, Halifax

Beazley K, Long R, MacKay P(2000) Focal species for marine reserve design. Unpublished report for The Greater Laurentian Wildlands Project, South Burlington, VT

Biro PA (1998) Staying cool: behavioral thermoregulation during summer by youngof-year brook trout in a lake. Trans Am Fish Soc 127:212-222

Blann K, Nerbonne JF, Vondracek B (2002) Relationship of riparian buffer type to water temperature in the Driftless Area Ecoregion of Minnesota. N Am J Fish Manag 22:441-451

Davis DS, Browne S (1996) The natural history of Nova Scotia, Volume 2. Topics and habitats, $2^{\text {nd }}$ edn. Nimbus Publishing and Nova Scotia Museum, Halifax

DFO (Department of Fisheries and Oceans) (2000) The effects of acid rain on the Atlantic salmon of the southern upland of Nova Scotia. DFO Maritimes Regional Habitat Status Report 2000/2E, DFO Maritimes Region, Dartmouth, NS

Eaton JG, Scheller RM (1996) Effects of climate warming on fish thermal habitat in streams of the United States. Limnol Oceanog 41:1109-1115

Elderkin MF, Boates JS (1996) Proposal for ranking species in Nova Scotia under the national framework for endangered species conservation. Nova Scotia Department of Natural Resources, Kentville, NS

Epifanio J, Haas G, Pratt K, Rieman B, Spruell P, Stockwell C, Utter F, Young W (2003) Integrating conservation genetic considerations into conservation planning: a case study of bull trout in the Lake Pend Oreille-lower Clark Fork River system. Fisheries (Bethesda) 28:10-24

Fausch KD (1988) Tests of competition between native and introduced salmonids in streams: what have we learned? Can J Fish Aquat Sci 45:2238-2246

Fausch KD, Torgersen CE, Baxter CV, Li HW (2002) Landscapes to riverscapes: bridging the gap between research and conservation of stream fishes. BioScience 52:483-498 
Frenzel SA, Swanson RB (1996) Relations of fish community composition to environmental variables in streams of Central Nebraska, USA. Environ Manag 20:689-705

Gilhen J (1974) The fishes of Nova Scotia's lakes and streams. Nova Scotia Museum, Halifax

Gilhen J (2002) (Nova Scotia Museum, Halifax) Personal communication

Gomi T, Sidle RC, Richardson JS (2002) Understanding processes and downstream linkages of headwater systems. BioScience 52:905-916

Halliwell DB, Langdon RW, Daniels RA, Kurtenbach JP, Jacobson RA (1998) Classification of freshwater fish species of the northeastern United States for use in the development of indices of biological integrity, with regional applications. In: Simon TP (ed) Assessing the sustainability and biological integrity of water resources using fish communities. CRC Press, Boca Raton, FL, p 301-337

Hengeveld HG (2000) Climate change digest: projections for Canada's climate future. Environ Canada, Downsview, ON

Hughes RM, Noss RF (1992) Biological diversity and biological integrity: current concerns for lakes and streams. Fisheries (Bethesda) 17:11-19

Hughes RM, Whittier RR, Rohm CM, Larsen DP (1990) A regional framework for establishing recovery criteria. Environ Manag 14:673-683

Kanno Y (2002) Fish community changes in River Philip, Nova Scotia, and an index of sustainable coldwater streams (ISCS). MES thesis, Dalhousie University, Halifax

Karr JR, Chu EW (1999) Restoring life in running waters: better biological monitoring. Island Press, Washington, DC

Karr JR, Fausch KD, Angermeier PL, Yant PR, Schlosser IJ (1986) Assessing biological integrity in running waters: a method and its rationale. Spec Publ 5, Illinois Natural History Survey, Champaign, IL

Kauffman JB, Beschta RL, Otting N, Lytjen D (1997) An ecological perspective of riparian and stream restoration in the western United States. Fisheries (Bethesda) 22:12-24

Kerans BL, Karr JR (1994) A benthic index of biotic integrity (B-IBI) for rivers of the Tennessee Valley. Ecol Appl 4:768-785

Lambeck RJ (1997) Focal species: a multi-species umbrella for nature conservation. Conserv Biol 11:849-856

Lyons J, Wang L, Simonson TD (1996) Development and validation of an index of biotic integrity for coldwater streams in Wisconsin. N Am J Fish Manag 16:241-256

Magnuson JJ, Crowder LB, Medvick PA (1979) Temperature as an ecological resource. Am Zool 19:331-343

Maitland PS (1985) Criteria for the selection of important sites for freshwater fish in the British Isles. Biol Conserv 31:335-353

Meka JM, Knudsen EE, Kann J (2003) Variable migratory patterns of different adult rainbow trout life history types in a southwest Alaska watershed. Trans Am Fish Soc 132:717-732

Miller B, Reading R, Strittholt J, Carroll C and 7 others (1999) Using focal species in the design of nature reserve networks. Wild Earth, Winter 1998/99:81-85, 88-92

Miller RR, Williams JD, Williams JE (1989) Extinctions of North American fishes during the past century. Fisheries (Bethesda) 14:22-38

Moyle PB, Leidy RA (1992) Loss of biodiversity in aquatic ecosystems: evidence from fish faunas. In: Fiedler PL, Jain SK (eds) Conservation biology: the theory and practice of nature conservation, preservation and management. Chapman \& Hall, New York, p 127-169 
Moyle PB, Sato GM (1991) On the design of preserves to protect native fishes. In: Minckley WL, Deacon JE (eds) Battle against extinction: native fish management in the American west. University of Arizona Press, Tucson, AZ, p 155-169

Moyle PB, Williams JE (1990) Biodiversity loss in the temperature zone: decline of the native fish fauna of California. Conserv Biol 4:275-284

Moyle PB, Marchetti MP (1998) Applications of indices of biotic integrity to California streams and watersheds. In: Simon TP (ed) Assessing the sustainability and biological integrity of water resources using fish communities. CRC Press, Boca Raton, FL, p 367-380

Mundahl ND, Simon TP (1998) Development and application of an index of biotic integrity for coldwater streams of the upper Midwestern United States. In: Simon TP (ed) Assessing the sustainability and biological integrity of water resources using fish communities. CRC Press, Boca Raton, FL, p 383-415

Newall PR, Magnuson JJ (1999) The importance of ecoregion versus drainage area on fish distributions in the St. Croix River and its Wisconsin tributaries. Environ Biol Fish 55:245-254

Nielsen JL, Lisle TE, OzakiV (1994) Thermally stratified pools and their use by steelhead in northern California streams. Trans Am Fish Soc 123:613-626

Noss RF, Dinerstein E, Gilbert B, Gilpin M, Miller BJ, Terborgh J, Trombulak S (1999) Core areas; where nature reigns. In: Soulé ME, Terborgh J (eds) Continental conservation: scientific foundations of regional reserve networks. Island Press, Washington, DC, p 99-128

NSDNR (Nova Scotia Department of Natural Resources) (2002) General status ranks of wild species in Nova Scotia. http://www.gov.ns.ca/natr/wildlife/genstatus

Olsen RA, Winter JD, Nettles DC, Haynes JM (1988) Resource partitioning in summer by salmonids in south-central Lake Ontario. Trans Am Fish Soc 117:552-559

Peterson JT, Bayley PB (1993) Colonization rates of fishes in experimentally defaunated warmwater streams. Trans Am Fish Soc 122:199-207

Peterson RH, Gale D (1991) Fish species associations in riffle habitat of streams of varying size and acidity in New Brunswick and Nova Scotia. J Fish Biol 38:859-871

Peterson RH, Martin-Robichaud DJ (1989) Community analysis of fish populations in headwater lakes of New Brunswick and Nova Scotia. Proc NS Inst Sci 38:55-72

Picard CR, Bozek MA, Momot WT (2003) Effectiveness of using summer thermal indices to classify and protect brook trout streams in northern Ontario. N Am J Fish Manag 23:206-215

Rahel FJ, Hubert WA (1991) Fish assemblage and habitat gradients in a Rocky MountainGreat Plains streams: biotic zonation and additive patterns of community change. Trans Am Fish Soc 120:319-332

Rahel FJ, Keleher CJ, Anderson JL (1996) Potential habitat loss and population fragmentation for cold water fish in the North Platte River drainage of the Rocky Mountains: response to climate warming. Limnol Oceanogr 41:1116-1123

Ricciardi A, Rasmussen JB (1999) Extinction rates of North American freshwater fauna. Conserv Biol 13:1220-1222

Rohm CM, Giese JW, Bennett CC (1987) Evaluation of an aquatic ecoregion classification of streams in Arkansas. J Freshw Ecol 4:127-140

Sheldon AL (1988) Conservation of stream fishes: patterns of diversity, rarity, and risk. Conserv Biol 2:149-156

Shuter BJ, Post JR (1990) Climate, population viability, and the zoogeography of temperate fishes. Trans Am Fish Soc 119:314-336 
Smith DL, Underwood JK, Ogden JG, Sabean BC (1986) Fish species distribution and water chemistry in Nova Scotia lakes. Water Air Soil Pollut 30:489-496

Snyder BD, Stribling JB, Barbour MT, Missimer CL (1998) Integrating assessments of fish and macroinvertebrate assemblages and physical habitat condition in Pennsylvania. In: Simon TP (ed) Assessing the sustainability and biological integrity of water resources using fish communities. CRC Press, Boca Raton, FL, p 639-652

Soulé ME, Noss R (1998) Rewilding and biodiversity: Complimentary goals for continental conservation. Wild Earth 8:18-28

Spidle AP, Kalinowski ST, Lubinski BA, Perkins DL, Beland KF, Kocik JF, King TL (2003) Population structure of Atlantic salmon in Maine with reference to populations from Atlantic Canada. Trans Am Fish Soc 132:196-209

Steedman RJ (1988) Modification and assessment of an index of biotic integrity to quantify stream quality in southern Ontario. Can J Fish Aquat Sci 45:492-501

Terborgh J, Estes JA, Paquet P, Ralls K, Boyd-Heger D, Miller BJ, Noss RF (1999) The role of top carnivores in regulating terrestrial ecosystems. In: Soulé ME, Terborgh J (eds) Continental conservation: scientific foundations of regional reserve networks. Island Press, Washington, DC, p 39-64

Waite IR, Carpenter KD (2000) Associations among fish assemblage structure and environmental variables in Willamette Basin streams, Oregon. Trans Am Fish Soc 129:754-770

Watt WD (1986) The case for liming some Nova Scotia salmon rivers. Water Air Soil Pollut 31:775-789

Whittier TR, Hughes RM, Larsen DP (1988) Correspondence between ecoregions and spatial patterns in stream ecosystems in Oregon. Can J Fish Aquat Sci 45:1264-1278

Williams JE, Johnson JE, Hendrickson DA, Contreras-Balderas S, Williams JD, Navarro-Mendoza M, McAllister DE, Deacon JE (1989) Fishes of North America endangered, threatened, or of special concern: 1989. Fisheries (Bethesda)14:2-20

Winston MR, Taylor CM, Pigg J (1991) Upstream extirpation of four minnow species due to damming of a prairie stream. Trans Am Fish Soc 120:98-105 